\title{
Aliivibrio finisterrensis sp. nov., isolated from Manila clam, Ruditapes philippinarum and emended description of the genus Aliivibrio
}

Correspondence

Jesús L. Romalde

jesus.romalde@usc.es

\author{
Roxana Beaz-Hidalgo, Alejandra Doce, Sabela Balboa, Juan L. Barja \\ and Jesús L. Romalde
}

\author{
Departamento de Microbiología y Parasitología, CIBUS-Facultad de Biología, Universidad de \\ Santiago de Compostela, 15782 Santiago de Compostela, Spain
}

\begin{abstract}
Four strains isolated from cultured Manila clam, Ruditapes philippinarum, in the north-western coast of Spain were characterized phenotypically and genotypically. Phylogenetic analyses based on the 16S rRNA gene sequences indicated that these bacteria were closely related to Aliivibrio wodanis, Aliivibrio salmonicida, Aliivibrio fischeri and Aliivibrio logei with sequence similarities between 98.1 and $96.0 \%$. Phylogenetic analysis based on the RNA polymerase alpha chain $(r p o A), \operatorname{Rec} A$ protein $(r e c A)$, the $\alpha$-subunit of bacterial ATP synthase $(\operatorname{atp} A)$ and the uridine monophosphate (UMP) kinase $(p y r H)$ genes and fluorescent amplified fragment length polymorphism experiments clearly showed that these novel isolates form a tight genomic group different from any currently known Aliivibrio species. On the basis of phylogenetic analysis and phenotypic data, the four strains represent a novel taxon, for which the name Aliivibrio finisterrensis sp. nov. is proposed. Several phenotypic features were revealed that discriminate $A$. finisterrensis from other Aliivibrio species. The type strain is CMJ $11.1^{\top}\left(=\mathrm{CECT} 7228^{\top}=\mathrm{LMG}^{\mathrm{N}}\right.$ $\left.23869^{\top}\right)$.
\end{abstract}

The controversy on the taxonomic position and phylogenetic relations of the Vibrio fischeri group, located between the genus Vibrio and Photobacterium (Sawabe et al., 2007), originated in the 1970s and has remained for decades (Reichelt \& Baumann, 1973; Baumann \& Baumann, 1977; Baumann et al. 1980; Thysen \& Ollevier, 2005). A recent study by Urbanczyk et al. (2007) demonstrated the phylogenetical and phenotypical distinction of the group from other genera in the family Vibrionaceae and proposed the novel genus Aliivibrio. The genus Aliivibrio contains four species: Aliivibrio fischeri and three psychrotolerant species, Aliivibrio salmonicida, Aliivibrio wodanis and

Abbreviations: MALDI-TOF MS, matrix-assisted laser desorption ionization-time of flight mass spectrometry; NJ, neighbour-joining; TEM, transmission electron microscopy.

The GenBank/EMBL/DDBJ accession numbers for the 16S rRNA, recA, rpo $A$, atp $A$ and $p y r H$ gene sequences of $A$. finisterrensis strains CMJ 11.1 ${ }^{\top}$, C 13.19, C 17.13 and VB 14.7 (CECT 7356) are EU541604, EU541586, EU541567, EU541561, EU889126, EU541614, EU541603, EU541583, EU541562, EU889127, EU541616, EU541598, EU541584, EU541563, EU889129, EU541615, EU931115-EU931117 and EU889128, respectively. The GenBank/EMBL/DDBJ accession number for the atpA gene sequence of Aliivibrio salmonicida NCIMB $2262^{\top}$ is EU541564.

Transmission electron micrograph of $A$. finisterrensis sp. nov, protein profile of the type strain of Vibrio gallaecicus, CMJ $11.1^{\top}$ obtained by the technique MALDI-TOF MS and three additional phylogenetic trees are available with the online version of this paper.
Alivibrio logei. A. fischeri, originally isolated by Beijerinck et al. (1889) (Urbanczyk et al. 2007), is known for the light organ symbiosis with the Hawaiian bobtail squid Euprymna scolopes and has been studied as a model for vibrio-host interactions. Bacterial bioluminescence acts as an anti-predatory mechanism and serves researchers as a way to monitor bacterial colonization (Stabb, 2006). A. salmonicida described by Egidius et al. (1986), is a psychrophilic species known as the causative agent of cold water vibriosis (Colquhoun \& Sørum, 2001) or the Hitra disease affecting Atlantic salmon (Salmo salar) (Egidius et al., 1981). A. wodanis (Lunder et al., 2000) also affects Atlantic salmon and has been associated with the winter ulcer disease (Lunder et al., 1995). A. logei shares characteristics with the other members of the genus. The bacterium is bioluminescent, has the ability to associate with salmonids reared at low temperatures and causes the Hitra disease (Benediktsdottir et al., 1998), but also resides symbiotically in light organs of several species of Mediterranean sepiolid squids. At lower temperatures $\left(15{ }^{\circ} \mathrm{C}\right)$ it is the dominant symbiont, whereas at higher temperatures $\left(26{ }^{\circ} \mathrm{C}\right)$ it is out-competed by $A$. fischeri (Fidopiastis et al., 1998; Nishiguchi, 2000).

Alivibrio related species and their hosts have been considered as models of either a co-evolution symbiosis or a pathogenic disease. To understand the driving force of the genetic diversity and speciation of $A$. fischeri related 
species is important to isolate novel species within this genus. In this study, we examined four strains from cultured Manila clams, Ruditapes philippinarum. Phylogenetic analysis and phenotypic characterization demonstrated that these strains represent an unknown species of the genus Aliivibrio.

During a sampling programme performed in the years 2004 and 2005, a collection of marine bacterial strains were isolated from different geographical sites on the northwestern coast of Spain. In a previous study, a representative number of isolates of this collection were analysed by amplified fragment length polymorphism and one of the clusters (cluster 86) with four strains [CMJ $11.1^{\mathrm{T}}(=\mathrm{CECT}$ $7228^{\mathrm{T}}=$ LMG $\left.23869^{\mathrm{T}}\right)$, VB $14.7(=$ CECT 7356), C $13.19, \mathrm{C}$ 17.13] could not be assigned to any of the currently known Vibrionaceae species (Beaz-Hidalgo et al., 2008). All strains were cultured on plates of marine agar (MA; Pronadisa) and were grown at $25 \pm 1{ }^{\circ} \mathrm{C}$ for $24 \mathrm{~h}$. The strains $A$. salmonicida NCIMB $2262^{\mathrm{T}}$, A. fischeri LMG $4414^{\mathrm{T}}, A$. wodanis ATCC BAA-104 ${ }^{\mathrm{T}}$ and A. logei LMG $19806^{\mathrm{T}}$ were also used in this study. Strains of A. wodanis (ATCC BAA$104^{\mathrm{T}}$ ) and A. salmonicida (NCIMB $2262^{\mathrm{T}}$ ) were grown at $15{ }^{\circ} \mathrm{C}$ for $24 \mathrm{~h}$. Stock cultures were maintained frozen at $-80{ }^{\circ} \mathrm{C}$ in marine broth (Pronadisa) supplemented with $15 \%$ glycerol $(\mathrm{v} / \mathrm{v})$. Biochemical characterization of the four clam isolates was performed by standard techniques, following the methodologies described by Lemos et al. (1985), Mac Faddin (1993), West et al. (1986) and Romalde \& Toranzo (1991). Further phenotypic characterization was performed using API 20E and API ZYM (bioMérieux) following the instructions of the manufacturer, with the exception of using saline solution $(0.85 \%)$ for the preparation of the inocula. Acid production of 50 carbon sources was tested by using the API $50 \mathrm{CH}$ system with slight modifications. Briefly, bacterial suspensions were prepared in saline solution $(0.85 \% \mathrm{NaCl})$, adjusted to an optical density of 1.0 at $580 \mathrm{~nm}$ and mixed $(1: 90, \mathrm{v} / \mathrm{v})$ with the ZOF medium (Lemos et al., 1985) for inoculation procedures (Prado, 2006).

Flagellar arrangement and cellular size were determined by transmission electron microscopy (TEM). For TEM, cells were stained with fosfotungstic acid $(2 \%)$ and processed samples were visualized by an electron microscope Philips CM-12.

Genomic DNA extraction, amplification and sequencing reactions of the $16 \mathrm{~S}$ rRNA gene were performed as previously described (Osorio et al., 1999). Sequencing of the genes $r p o A$, recA, atpA and $p y r H$ was carried out by the methods described by Thompson et al. (2004, 2005, 2007). Sequencing reactions were performed using the kit GenomeLab DTCS-Quick Start kit (Beckman Coulter). The 16S rRNA gene and four housekeeping genes were sequenced for all four strains. Sequencing was also performed for the strain A. salmonicida NCMB $2262^{\mathrm{T}}$ for the atpA gene due to its absence in the database. Sequence corrections and analysis were performed with DNASTAR
Seqman program (Lasergene). Sequences were retrieved and levels of gene sequence similarities were determined by using the EzTaxon (http://www.eztaxon.org/; Chun et al., 2007), leBIBI (http://umr5558-sud-str1.univ-lyon1.fr/ lebibi/lebibi.cgi; Devulder et al., 2003) and NCIMB/BLAST (http://blast.ncbi.nlm.nih.gov/) release servers. Phylogenetic relationships between representatives of Vibrio and Alivibrio species were determined by using MEGA version 4.0 software program (Tamura et al., 2007). Distance matrices were determined (Kimura, 1980) and these matrices were used to elaborate dendrograms by using the neighbour-joining (NJ) method (Saitou \& Nei, 1987). A bootstrap analysis to investigate the stability of the trees was performed on 1000 replicates.

DNA-DNA hybridization experiments, including reciprocal analysis, were done in duplicate by the hydroxyapatite/microtitre plate method (Ziemke et al., 1998) with a hybridization temperature $\left(T_{\mathrm{m}}\right)$ of $60{ }^{\circ} \mathrm{C}$.

The protein analysis by matrix-assisted laser desorption ionization-time of flight mass spectrometry (MALDI-TOF MS) was performed in the mass spectrometry unit of the University of Santiago de Compostela. Protein extraction was performed with ethanol, formic acid and acetonitrile. Processed samples were placed in a 96-well plate, allowed to dry and covered with a matrix solution ( $\alpha$-cyano-4hydroxycinnamic acid). Mass spectra were obtained using a MALDI-TOF Autoflex mass spectrometer (Bruker Daltronics). The measured mass range of spectra was 2000-20000 Da. Peak comparison was done with the database of Bruker Daltronics. The species-limit value considered was 2300 . Identification to genus level was in the range 1700-1999. As a positive control Escherichia coli CECT 433 was included in the analysis and protein profiles were compared with its own profiles.

Cells of the novel Alivibrio species were large rods of size $1.36-2.15 \mu \mathrm{m}$ in length and $0.80-1.05 \mu \mathrm{m}$ in width and occurred singly, in pairs or as aggregates of many cells. The presence of a polar flagellum was observed by TEM (Supplementary Fig. S1, available in IJSEM Online).

All strains isolated were motile, facultative anaerobic, Gram-negative, oxidase-positive rods and susceptible to the vibriostatic agent $\mathrm{O} / 129$ (150 $\mu \mathrm{g}$ per disc). They were able to grow only in media supplemented with $\mathrm{NaCl}$ (from 0.5 to $6 \%$ ) between 4 and $30{ }^{\circ} \mathrm{C}$, and reduced nitrates to nitrites. The four clam strains were phenotypically homogeneous, with six variable traits, such as production of acid from arbutin, D-mannitol, sucrose and melibiose, with strain $\mathrm{C} 17.13$ being more reactive than the rest of the isolates. Several useful differentiating features were disclosed that discriminate this group of isolates from other related Alivivibrio and Vibrio species (Table 1). All strains failed to grow on media supplemented with $0.5 \% \mathrm{NaCl}$ and were positive for Moeller's arginine dihydrolase and the urea test unlike the other four Alivibrio species. 
Table 1. Differential phenotypic characteristics of strain A. finisterrensis and the type strains of related Aliivibrio and Vibrio species

Taxa (species/strains) are indicated as: 1 , A. finisterrensis CMJ $11.1^{\mathrm{T}}\left(=\mathrm{CECT} 7228^{\mathrm{T}}=\mathrm{LMG} 23869^{\mathrm{T}}\right.$ ) (four strains); 2, A. fischeri NCMB $1281^{\mathrm{T}} ; 3$, A. wodanis ATCC BAA-104 ${ }^{\mathrm{T}}$; 4, A. logei LMG $19806^{\mathrm{T}}$; 5, A. salmonicida NCMB $2262^{\mathrm{T}}$; 6, Vibrio aestuarianus ATCC $35048^{\mathrm{T}}$; 7, Vibrio mediterranei CECT $621^{\mathrm{T}} ; 8$, Vibrio metschnikovii ATCC $7708^{\mathrm{T}}$; 9, Vibrio orientalis CECT $629^{\mathrm{T}} ; 10$, Vibrio proteolyticus ATCC $15338^{\mathrm{T}}$. + , Positive; -, negative; $\mathrm{v}-$, variable but type strain is negative (percentage of strains testing positive are in parentheses). All strains were positive for catalase, oxidase, motility, growth at $15{ }^{\circ} \mathrm{C}$, growth in $3 \% \mathrm{NaCl}$, susceptibility to the vibriostatic agent and ampicillin, degradation of DNA, fermentation of D-glucose and acid production from alkaline phosphatase. All strains were negative for Gram stain, production of ornithine decarboxylase, degradation of alginate, acid production from inositol, L-arabinose, melibiose, raffinose, L-rhamnose, D-sorbitol and D-xylose, production of cysteine arylamidase, $\alpha$-chymotrypsinase, $\alpha$-glucosidase, $\beta$-glucosidase, $\beta$-glucuronidase, $\alpha$-mannosidase and $\alpha$-fucosidase.

\begin{tabular}{|c|c|c|c|c|c|c|c|c|c|c|}
\hline Characteristic & 1 & 2 & 3 & 4 & 5 & 6 & 7 & 8 & 9 & 10 \\
\hline \multicolumn{11}{|l|}{ Production of } \\
\hline Arginine dihydrolase & + & - & - & - & - & + & + & + & - & + \\
\hline Indole & - & + & + & - & - & + & + & - & + & + \\
\hline Urea & + & + & - & - & - & - & - & - & - & - \\
\hline Voges-Proskauer & - & + & - & - & - & - & - & + & - & + \\
\hline \multicolumn{11}{|l|}{ Degradation of: } \\
\hline Starch & - & - & + & - & - & + & + & + & + & + \\
\hline Gelatin & - & - & + & - & - & + & - & + & + & - \\
\hline Tween 80 & + & + & + & + & - & + & + & + & + & + \\
\hline \multicolumn{11}{|l|}{ Production of acid from: } \\
\hline Cellobiose & + & - & - & + & - & + & + & - & + & + \\
\hline Sucrose & $\mathrm{v}-(25)$ & + & + & - & - & + & + & + & + & - \\
\hline Trehalose & - & - & + & + & + & + & + & + & + & + \\
\hline \multicolumn{11}{|l|}{ Growth in $\mathrm{NaCl}(\%, \mathrm{w} / \mathrm{v})$ : } \\
\hline 0.5 & - & + & + & + & + & - & + & + & + & + \\
\hline 8 & - & + & - & - & - & + & + & - & + & + \\
\hline \multicolumn{11}{|l|}{ Growth at $\left({ }^{\circ} \mathrm{C}\right)$ : } \\
\hline 4 & + & - & + & + & + & + & - & - & + & - \\
\hline 25 & + & + & + & - & - & + & + & + & + & + \\
\hline 30 & + & + & - & - & - & + & + & + & + & + \\
\hline 35 & - & + & - & - & - & - & - & + & + & + \\
\hline \multicolumn{11}{|l|}{ API ZYM tests: } \\
\hline
\end{tabular}

The results of the phylogenetic analysis based on the $16 \mathrm{~S}$ rRNA gene showed clearly that the strains belong to subgroup 3 of the class Gammaproteobacteria. The phylogenetic tree based on the $16 \mathrm{~S}$ rRNA gene sequences confirmed the clustering of the clam strains $\mathrm{CMJ} 11.1^{\mathrm{T}}, \mathrm{VB}$ 14.7, C 13.19 and C 17.13, with a bootstrap value of $100 \%$, and their distinction from their closest phylogenetic neighbours (Supplementary Fig. S2, available in IJSEM Online). These strains showed high levels of 16S rRNA gene sequence similarity to each other above $99.9 \%$. Gene sequence similarities of the strain $\mathrm{CMJ} 11.1^{\mathrm{T}}$ with close phylogenetic neighbours were $98.1 \%$ with $A$. wodanis $\left(\right.$ ATCC BAA-104 $\left.{ }^{\mathrm{T}}\right), 97.8 \%$ with A. logei $\left(\mathrm{LMG} 19806^{\mathrm{T}}\right)$,
97.1\% with A. fischeri (LMG $4414^{\mathrm{T}}$ ) and $96.0 \%$ with $A$. salmonicida (NCMB $2262^{\mathrm{T}}$ ).

The clustering of the novel species isolates was also observed in phylogenetic trees based on the housekeeping genes (Supplementary Fig. S3, available in IJSEM Online). Similarities for rpoA sequences ranged between 98.1 (CMJ $11.1^{\mathrm{T}}$ and A. wodanis ATCC BAA- $104^{\mathrm{T}}$ ) and $97.2 \%(\mathrm{CMJ}$ $11.1^{\mathrm{T}}$ and $A$. fischeri LMG $\left.4414^{\mathrm{T}}\right)$. For recA sequences, similarities ranged from $89.0\left(\mathrm{CMJ} 11.1^{\mathrm{T}}\right.$ and $A$. fischeri LMG $\left.4414^{\mathrm{T}}\right)$ to $81.0 \%\left(\mathrm{CMJ} 11.1^{\mathrm{T}}\right.$ and A. salmonicida NCMB $2262^{\mathrm{T}}$ ), whereas for atpA sequences similarities ranged from $95.1\left(\mathrm{CMJ} 11.1^{\mathrm{T}}\right.$ and A. wodanis ATCC BAA- 
$104^{\mathrm{T}}$ ) to $92.0 \%\left(\mathrm{CMJ} 11.1^{\mathrm{T}}\right.$ and $A$. salmonicida NCMB $\left.2262^{\mathrm{T}}\right)$. Finally, similarities in pyrH sequences ranged between $90.0\left(\mathrm{CMJ} 11.1^{\mathrm{T}}\right.$ with $A$. wodanis ATCC BAA-104 ${ }^{\mathrm{T}}$ and $A$. salmonicida NCMB $2262^{\mathrm{T}}$ ) and $87 \%\left(\mathrm{CMJ} 11.1^{\mathrm{T}}\right.$ and $A$. fischeri LMG $4414^{\mathrm{T}}$ ). A concatenated tree based on the 16S rRNA gene and four housekeeping genes revealed a robust clade of the strains analysed in this study with $100 \%$ bootstrap value, not including any species with validly published names (Fig. 1 and Supplementary Fig S4, available in IJSEM Online).

DNA-DNA hybridization values of strain CMJ $11.1^{\mathrm{T}}$ against the four species in the genus were $32.8 \%$ with $A$. fischeri $\mathrm{LMG} 4414^{\mathrm{T}}, 32.4 \%$ with $A$. salmonicida NCMB $2262^{\mathrm{T}}, 46.5 \%$ with $A$. logei LMG $19806^{\mathrm{T}}$ and $66.5 \%$ with A. wodanis ATCC $\mathrm{BAA}-104^{\mathrm{T}}$, being below the $70 \%$ threshold established to delineate a novel species (Wayne et al., 1987). Reciprocal analysis rendered values of hybridization of $65.5,41.6,34.6$ and $27.5 \%$ between $A$. wodanis ATCC BAA-104 ${ }^{\mathrm{T}}$, A. logei LMG $19806^{\mathrm{T}}, A$. salmonicida NCMB $2262^{\mathrm{T}}$ and A. fischeri LMG $4414^{\mathrm{T}}$, with CMJ11.1 ${ }^{\mathrm{T}}$, respectively. Hybridization values between the type strain CMJ $11.1^{\mathrm{T}}$, and the rest of the strains C $13.19, \mathrm{C}$ 17.13 and VB 14.7 were $80.1,90.0$ and $86.5 \%$, respectively.

A unique protein profile was obtained for the strain CMJ $11.1^{\mathrm{T}}$ (Supplementary Fig. S5, available in IJSEM Online), differentiating them from closely related species present in the database. The closest species defined by MALDI-TOF MS was A. fischeri (score=1.671). A correct identification of E. coli CECT 433 was obtained, with profiles always above 2.300 in score.

Genotypic and phenotypic data described in this study clearly demonstrate that the four isolates should be accommodated in a novel species in the genus Aliivibrio namely Alivibrio finisterrensis with the strain CMJ $11.1^{\mathrm{T}}$ as the type strain.

\section{Description of Aliivibrio finisterrensis sp. nov.}

Aliivibrio finisterrensis [fi.nis.ter.ren'sis. N.L. masc. adj. finisterrensis pertaining to Finisterra, literally the end of the world (at least for the Romans who named this place). Galicia was the western end of the ancient Roman world].

Cells are Gram-negative rods, motile and facultative anaerobic. Colonies are round with smooth margins, translucent and non-swarming on MA plates. Strains grow on TCBS agar producing colonies of size 1.0-1.5 $\mathrm{mm}$ after $24 \mathrm{~h}$ of incubation. One strain (C 17.13) produces cream colonies on MA and yellow colonies on TCBS, the other strains produce green colonies. Glucose metabolism is fermentative without gas production. Strains reduce nitrates to nitrites. Oxidase, catalase and ONPG tests are positive. Sensitive to the vibriostatic agent O/129 (150 $\mu \mathrm{g}$ per disc) and resistant to ampicillin (10 $\mu \mathrm{g}$ per disc), and are able to grow at $4{ }^{\circ} \mathrm{C}$ but not at $35^{\circ} \mathrm{C}$ nor at 0.5 or $8 \%$ $\mathrm{NaCl}(\mathrm{w} / \mathrm{v})$. Optimal $\mathrm{NaCl}$ concentration for growth is 1$3 \%(\mathrm{w} / \mathrm{v})$. Not luminescent. All strains are positive for arginine and lysine decarboxylase, urea and methyl red tests. Tests for ornithine decarboxylase, indole, VogesProskauer and use of citrate are negative. Strains do not hydrolyse starch, gelatin or alginate. All strains are positive for DNase, Tween 80 and aesculin activities. Acid is produced from the following compounds: glycerol, Dglucose, D-ribose, D-galactose, D-fructose, D-mannose, $\mathrm{N}$ acetylglucosamine, salicin, cellobiose, maltose, lactose (bovine origin), gentiobiose and potassium 2-ketogluconate. Half of the strains produce acid from arbutin and melibiose. Strain CMJ $11.1^{\mathrm{T}}$ and $\mathrm{C} 13.19$ are positive for the production of acid from arbutin, type strain only also for melibiose, and strain C 17.13 for D-mannitol and sucrose. None of the strains produce acid from erythritol, D-arabinose, L-arabinose, D-xylose, L-xylose, D-adonitol, methyl $\beta$-D-xylopyranoside, L-sorbose, L-rhamnose, dulci-

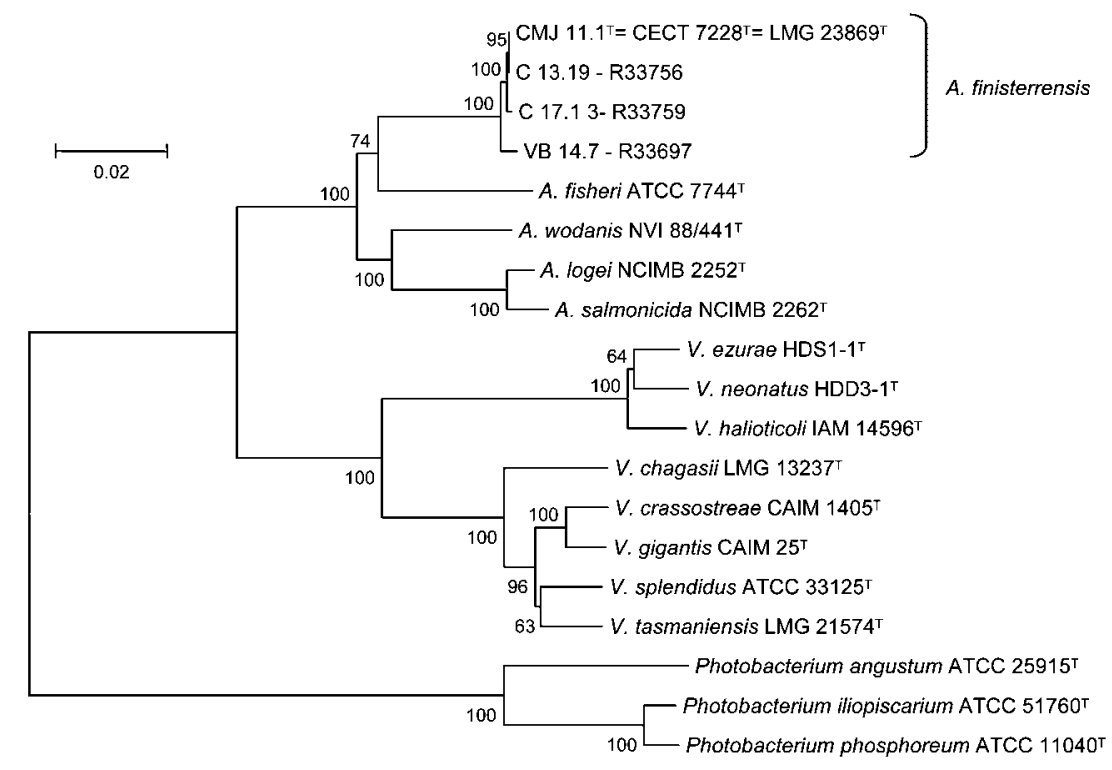

Fig. 1. Phylogenetic tree based on concatenated sequences of four housekeeping genes $\operatorname{rec} A, r p o A, p y r H$ and atp $A$ and the 16S rRNA gene obtained by the $\mathrm{NJ}$ method. Horizontal branch lengths are proportional to evolutionary divergence. Bootstrap percentages from 1000 replicates appear next to the corresponding branch. A similar topology was found by the maximum-likelihood method (see Supplementary Fig. S4). 
tol, inositol, starch, glycogen, D-sorbitol, methyl $\alpha$-Dmannopyranoside, methyl $\alpha$-D-glucopyranoside, amygdalin, trehalose, inulin, melezitose, D-raffinose, xylitol, turanose, D-lyxose, D-tagatose, D-fucose, L-fucose, Darabitol, L-arabitol and potassium 5-ketogluconate. API ZYM reaction tests were positive in all strains for alkaline phosphatase, esterase lipase, leucine arylamidase and $\mathrm{N}$ acetyl- $\beta$-glucosaminidase. Strain C 17.13 also showed positive results for esterase $(\mathrm{C} 4)$ and valine arylamidase.

The type strain, CMJ $11.1^{\mathrm{T}}\left(=\mathrm{CECT} 7228^{\mathrm{T}}=\mathrm{LMG} 23869^{\mathrm{T}}\right)$, was isolated from clam Ruditapes philippinarum in the north-western coast of Spain.

\section{Emended description of the genus Aliivibrio}

Gram-negative, motile, rod-shaped cells with one or more sheathed flagella. Conforms to the description of the family Vibrionaceae. Some strains are luminous. Oxidase-positive, fermentative and can utilize glucose as a sole carbon source; sensitive to the vibriostatic agent $\mathrm{O} / 129$ at $10 \mu \mathrm{g}$. Grow on media with $1 \%$, but not with $10 \% \mathrm{NaCl}$. Species are ornithine decarboxylase-negative, do not hydrolyse gelatin and do not form acetoin (Voges-Proskauer test). A. fischeri and $A$. finisterrensis are urease-positive and ferment gentiobiose; all other species of the genus are negative for these two characteristics. All species utilize acetate as a sole carbon source except A. fischeri. Species other than $A$. salmonicida and $A$. finisterrensis have yellow-orange cellassociated pigment. The DNA G $+\mathrm{C}$ content is between 38 and $42 \mathrm{~mol} \%$. Found in the marine environment, often associated with animals; some species are mutualistic symbionts or pathogens of marine animals. Member of the class Gammaproteobacteria. The type species is Aliivibrio fischeri.

\section{Acknowledgements}

This work was supported in part by grants AGL2003-09307-C02-01 and AGL2006-13208-C02-01, from the Ministerio de Ciencia y Tecnología and grant PGIDIT04PXIC20001PN from the Xunta de Galicia (Spain). R. B.-H. and S. B. acknowledge the Ministerio de Ciencia y Tecnología (Spain) for research fellowship.

\section{References}

Baumann, P. \& Baumann, L. (1977). Biology of the marine enterobacteria: genera Beneckea and Photobacterium. Annu Rev Microbiol 31, 39-61.

Baumann, P., Baumann, L., Bang, S. S. \& Woolkalis, M. J. (1980). Reevaluation of the taxonomy of Vibrio, Beneckea, and Photobacterium: abolition of the genus Beneckea. Curr Microbiol 4, 127-132.

Beaz Hidalgo, R., Cleenwerck, I., Balboa, S., De Wachter, M., Thompson, F. L., Swings, J., De Vos, P. \& Romalde, J. L. (2008). Genomic diversity amongst Vibrio isolates associated with clam culture in Galicia (NW of Spain). Syst Appl Microbiol 31, 215-222.

Benediktsdottir, E., Helgason, S. \& Sigurjonsdottir, H. (1998). Vibrio spp. isolated from salmonids with shallow skin lesions and reared at low temperature. J Fish Dis 21, 19-28.
Chun, J., Lee, J. H., Jung, Y., Kim, M., Kim, S., Kim, B. K. \& Lim, Y. W. (2007). EzTaxon: a web-based tool for the identification of prokaryotes based on $16 \mathrm{~S}$ ribosomal RNA gene sequences. Int J Syst Evol Microbiol 57, 2259-2261.

Colquhoun, D. J. \& Sørum, H. (2001). Temperature dependent siderophore production in Vibrio salmonicida. Microb Pathog 31, 213219.

Devulder, G., Perriére, G., Baty, F. \& Flandrois, J. P. (2003). BIBI, a Bioinformatics Bacterial Identification Tool. J Clin Microbiol 41, 1785-1787.

Egidius, E., Andersen, K., Clausen, E. \& Raa, J. (1981). Cold water vibriosis or "Hitra disease" in Norwegian salmonid farming. J Fish Dis 4, 353-354.

Egidius, E., Wiik, R., Andersen, K., Hoff, K. A. \& Hjeltnes, B. (1986). Vibrio salmonicida sp. nov., a new fish pathogen. Int J Syst Bacteriol 36, 518-520.

Fidopiastis, P. M., von Boletzky, S. \& Ruby, E. G. (1998). A new niche for Vibrio logei, the predominant light organ symbiont of squids in the genus Sepiola. J Bacteriol 180, 59-64.

Kimura, M. (1980). A simple method for estimating evolutionary rates of base substitutions through comparative studies of nucleotide sequences. J Mol Evol 16, 111-120.

Lemos, M. L., Toranzo, A. E. \& Barja, J. L. (1985). Modified medium for the oxidation-fermentation test in the identification of marine bacteria. Appl Environ Microbiol 49, 1541-1543.

Lunder, T., Evensen, Ø., Holstad, G. \& Hastein, T. (1995). “Winter ulcer" in the Atlantic salmon Salmo salar. Pathological and bacteriological investigations and transmission experiments. Dis Aquat Organ 23, 39-49.

Lunder, T., Forum, H., Holstad, G., Steigerwalt, A. G., Mowinckel, P. \& Brenner, D. J. (2000). Phenotypic and genotypic characterization of Vibrio viscosus sp. nov. and Vibrio wodanis sp. nov. isolated from Atlantic salmon (Salmo salar) with "winter ulcer". Int J Syst Evol Microbiol 50, 427-450.

Mac Faddin, J. F. (1993). Pruebas bioquímicas para la identificación de bacterias de importancia clinica. Baltimore: The William \& Wilkins Company. Translation by Médica Panamericana S.A.

Nishiguchi, M. K. (2000). Temperature affects species distribution in symbiotic populations of Vibrio spp. Appl Environ Microbiol 66, 35503555.

Osorio, C. R., Collins, M. D., Toranzo, A. E. \& Romalde, J. L. (1999). 16S rRNA gene sequence analysis of Photobacterium damselae and nested PCR method for rapid detection of fish pasteurellosis. Appl Environ Microbiol 65, 2942-2946.

Prado, S. (2006). Microbiota asociada a criaderos de moluscos: Patogénesis y Probiosis. PhD thesis. Universidad de Santiago de Compostela, Spain.

Reichelt, J. L. \& Baumann, P. (1973). Taxonomy of marine luminous bacteria. Arch Microbiol 94, 283-330.

Romalde, J. L. \& Toranzo, A. E. (1991). Evaluation of the API 20E system for the routine diagnosis of the enteric redmouth disease. Bull Eur Assoc Fish Pathol 11, 147-149.

Saitou, N. \& Nei, M. (1987). The neighbor-joining method: a new method for reconstructing phylogenetic trees. Mol Biol Evol 4, 406-425.

Sawabe, T., Kita-Tsukamoto, K. \& Thompson, F. L. (2007). Inferring the evolutionary history of vibrios by means of multilocus sequence analysis. J Bacteriol 189, 7932-7936.

Stabb, E. (2006). The Vibrio fischeri-Euprymna scolopes light organ symbiosis. In The Biology of Vibrios, pp. 204-218. Edited by F. L. Thompson, B. Austin \& J. Swings. Washington, DC: American Society for Microbiology. 
Tamura, K., Dudley, J., Nei, M. \& Kumar, S. (2007). MEGA4: Molecular Evolutionary Genetics Analysis (MEGA) software version 4.0. Mol Biol Evol 24, 1596-1599.

Thompson, C. C., Thompson, F. L., Vandemeulebroecke, K., Hoste, B., Dawyndt, P. \& Swings, J. (2004). Use of recA as an alternative phylogenetic marker in the family Vibrionaceae. Int J Syst Evol Microbiol 54, 919-929.

Thompson, F. L., Gevers, D., Thompson, C. C., Dawyndt, P., Naser, S., Hoste, B., Munn, C. B. \& Swings, J. (2005). Phylogeny and molecular identification of vibrios on the basis of multilocus sequence analysis. Appl Environ Microbiol 71, 5107-5115.

Thompson, C. C., Thompson, F. L., Vicente, A. C. \& Swings, J. (2007). Phylogenetic analysis of vibrios and related species by means of atpA gene sequences. Int J Syst Evol Microbiol 57, 2480-2484.

Thysen, A. \& Ollevier, F. (2005). Genus II. Photobacterium Beijerinck $1889,401^{\mathrm{AL}}$. In Bergey's Manual of Systematic Bacteriology, 2nd edn, vol. 2, part B, pp. 546-552. Edited by D. J. Brenner, N. R. Krieg, J. T. Staley \& G. M. Garrity. New York: Springer.
Urbanczyk, H., Ast, J. C., Higgins, M. J., Carson, J. \& Dunlap, P. V. (2007). Reclassification of Vibrio fischeri, Vibrio logei, Vibrio salmonicida and Vibrio wodanis as Alivibrio fischeri gen. nov., comb. nov., Allivibrio logei comb. nov., Allivibrio salmonicida comb. nov. and Aliivibrio wodanis comb. nov. Int J Syst Evol Microbiol 57, 2823-2829.

Wayne, L. G., Brenner, D. J., Colwell, R. R., Grimont, P. A. D., Kandler, O., Krichevsky, M. I., Moore, L. H., Moore, W. E. C., Murray, R. G. E. \& other authors (1987). International Committee on Systematic Bacteriology. Report of the ad hoc committee on reconciliation of approaches to bacterial systematics. Int $J$ Syst Bacteriol 37, 463-464.

West, P. A., Brayton, P. R., Bryant, T. N. \& Colwell, R. R. (1986). Numerical taxonomy of vibrios isolated from aquatic environments. Int J Syst Bacteriol 36, 531-543.

Ziemke, F., Hofle, M. G., Lalucat, J. \& Roselló-Mora, R. (1998). Reclassification of Shewanella putrefaciens Owen's genomic group II as Shewanella baltica sp. nov. Int J Syst Bacteriol 48, 179-186. 